\title{
Unrestricted Feed Intake During the Dry Period Impairs the Postpartum Oxidation and Synthesis of Fatty Acids in the Liver of Dairy Cows
}

\author{
A. Murondoti, ${ }^{3,4}$ R. Jorritsma, ${ }^{2}$ A. C. Beynen, ${ }^{3}$ T. Wensing, ${ }^{2}$ and M. J. H. Geelen ${ }^{1,3}$ \\ ${ }^{1}$ Laboratory of Veterinary Biochemistry, \\ ${ }^{2}$ Department of Farm Animal Health and \\ ${ }^{3}$ Department of Nutrition, \\ Graduate School of Animal Health, \\ Faculty of Veterinary Medicine, \\ Utrecht University, Utrecht, The Netherlands \\ ${ }^{4}$ Department of Clinical Veterinary Studies, \\ Faculty of Veterinary Science, \\ University of Zimbabwe, Harare, Zimbabwe
}

\begin{abstract}
The purpose of this study was to determine the activities of key hepatic enzymes of fatty acid synthesis and oxidation in cows that had excessive body fat at parturition. Dairy cows were allocated to either an experimental group or a control group. All cows were offered a total mixed ration with an energy content of $6.6 \mathrm{MJ}$ of net energy for lactation per kilogram of dry matter and consisting of corn silage, beet pulp, rapeseed meal, and soybean meal. Control cows were restricted to $6.8 \mathrm{~kg} /$ dry matter of the mixed ration in the dry period. Experimental cows had unrestricted access to the mixed ration during the dry period to increase body fat and induce fatty liver postpartum. Blood and liver samples were collected 1 wk before and 1, 2, and 4 wk after parturition. Before parturition, neither the serum nonesterified fatty acids nor the hepatic triacylglycerol concentrations differed between experimental and control cows. After parturition, the values for these variables were greater in experimental cows than in control cows. Plasma 3-hydroxybutyrate increased sharply after parturition in the experimental group. In liver, the activity of acetyl-CoA carboxylase was already significantly lower in the experimental group before parturition. After parturition, the activities of acetyl-CoA carboxylase and fatty acid synthase dropped in the experimental group. The activity of 3-hydroxy-acyl-CoA dehydrogenase in liver was less in experimental cows following parturition. Hepatic citrate synthase activity increased only in the control group after parturition. Unrestricted feed intake before parturition reduces de novo fatty acid synthesis as well as fatty acid oxidation after parturi-
\end{abstract}

Received April 4, 2003

Accepted August 7, 2003.

Corresponding author: M. J. H. Geelen; e-mail: m.j.h.geleen@ vet.uu.nl. tion. The reduction in fatty acid oxidation following parturition may contribute to postpartum accumulation of triacylglycerol in the livers of cows with unrestricted access to feed during the dry period.

(Key words: dairy cow, de novo fatty acid synthesis, fatty acid oxidation, fatty liver)

Abbreviation key: ACC = acetyl-CoA carboxylase, CS $=$ citrate synthase, FAS = fatty acid synthase, $\mathbf{3 -}$ HAD = 3-hydroxy-acyl-CoA dehydrogenase, NEB = negative energy balance, $\mathbf{T A G}=$ triacylglycerol(s).

\section{INTRODUCTION}

High-producing dairy cows go into negative energy balance (NEB) after parturition because the extra energy requirement for milk production is not met by feed energy intake (Harrison et al., 1990; McNamara, 1991). As a consequence of NEB, cows mobilize fatty acids from adipose tissue to compensate for the deficit of glucose and fatty acids that causes an increase in the postpartum circulating concentrations of NEFA (Waltner et al., 1993; Zurek et al., 1995). In the liver, the NEFA are used for energy production, for the formation of ketone bodies, or are converted into triacylglycerols (TAG) and then secreted with very low density lipoproteins. When the formation of TAG is in excess of the capacity for secretion, TAG accumulate, resulting in the condition known as fatty liver (Herdt, 1988).

Fatty liver is a common postpartum condition in the high-producing cow, and it is associated with diseases such as mastitis, ketosis, infertility, displaced abomasum, and endometritis (Gerloff et al., 1986; Grummer, 1995; Oikawa et al., 1997). The risk of fatty liver development is enhanced in cows with excessive body fat at calving (Grummer, 1995). Such cows have lower feed intake postpartum than cows with normal condition (Treacher et al., 1986; Van den Top et al., 1996). Therefore, the former cows inevitably enter a larger NEB 
postpartum. The increase in the rate of lipolysis in adipose tissue, as a consequence of this large NEB, results in a dramatic increase in circulating concentrations of NEFA, that in turn increases uptake by the liver and produces fatty liver (McNamara, 1991; Van den Top et al., 1996).

Fatty acids in hepatic TAG can be derived either from NEFA taken up or from de novo synthesis. As there is limited fat in ruminant feed, the contribution of the liver in fat homeostasis may be relevant. The rate of fatty acid oxidation in liver may determine whether fatty acids enter the pathway of esterification and end up in TAG. Fatty acid synthesis is achieved by the consecutive action of acetyl-CoA carboxylase (ACC) and fatty acid synthase (FAS). The product of the reaction catalyzed by ACC, i.e., malonyl-CoA, is precisely the physiological inhibitor of carnitine palmitoyltransferase-I, one of the key regulatory enzymes of long-chain fatty acid oxidation, so that coordinate control of synthesis and oxidation of fatty acids is achieved (Guzmán and Geelen, 1993). The role of hepatic fatty acid oxidation and synthesis de novo in the development of fatty liver of cows with excess body fat is not known. The aim of the present study was to investigate the synthesis and oxidation of fatty acids and their coordination in the liver of cows developing fatty liver postpartum. Therefore, dairy cattle had unrestricted access to feed during the dry period to increase body fat and induce fatty liver postpartum. Specifically, the experiment aimed at 1) determining the plasma concentrations of BHBA and NEFA, 2) measuring the TAG concentration in the liver, and 3) assaying the hepatic activities of key enzymes involved in oxidation and synthesis of fatty acids, i.e., ACC, FAS, 3-hydroxy-acyl-CoA dehydrogenase (3-HAD) and citrate synthase (CS).

\section{MATERIALS AND METHODS}

\section{Cows and Diets}

The experimental design was approved by the animal experiments committee of the Utrecht Faculty of Veterinary Medicine. Seventeen pregnant, multiparous Holstein-Friesian cows were allocated to two groups: 7 cows were assigned to the control group, and 10 cows were assigned to the experimental group. The objective of the study was to increase body fat in the experimental group during the dry period and to induce fatty liver postpartum. To enhance the contrast between the control and the experimental group, the cows with the highest BCS were allocated to the experimental group. The experimental group averaged $4.6 \pm 0.3 \mathrm{yr}$ of age, weighed $734 \pm 21 \mathrm{~kg}$ of BW, and had produced 8312 $\pm 285 \mathrm{~kg}$ of milk (cumulative $305-\mathrm{d}$ milk production), whereas the control group averaged $5.5 \pm 0.7 \mathrm{yr}$ of age,
Table 1. Ration composition.

\begin{tabular}{ll}
\hline & \% of DM \\
\hline Corn silage $^{1}$ & 52.3 \\
Solvent extracted rapeseed meal $^{2}$ & 7.7 \\
${\text { Solvent extracted soybean } \text { meal }^{2}}_{\text {Beet pulp, dehydrated }^{2}}$ & 17.2 \\
Minerals/Vitamins $^{3}$ & 21.8 \\
Total & 1 \\
Calculated energy content & 100 \\
\hline
\end{tabular}

${ }^{1}$ The analyzed composition ( $319 \mathrm{~g}$ of $\mathrm{DM} / \mathrm{kg}$ ) was as follows $(\mathrm{g} / \mathrm{kg}$ of DM): CP, 74; crude fiber, 186; starch, 361; crude ash, 46. The calculated energy content on the basis of analyzed crude fiber, CP, and crude ash was 6.6 $\mathrm{MJ} \mathrm{NE} / \mathrm{kg} \mathrm{DM}$ (Bedrijfslaboratorium voor Grond- en Gewasonderzoek, Oosterbeek, The Netherlands).

${ }^{2}$ Nutrient composition was taken from tabular data (Centraal Veevoederbureau, 2000).

${ }^{3}$ The mineral/vitamin mix contained the following ( $/ \mathrm{kg}$ ): vitamin A, 600000 IU; vitamin D, 200000 IU; vitamin E, 2 g; Ca, 150 g; P, 80 g; Na, 80 g; Mg, 100 g; Fe, 0.5 g; Mn, 4 g; Zn, 5 g; Cu, 3 g; Co, $0.1 \mathrm{~g} ; \mathrm{I}, 0.15 \mathrm{~g}$; Se, $0.04 \mathrm{~g}$.

weighed $613 \pm 16 \mathrm{~kg}$ of BW, and had produced $8535 \pm$ $530 \mathrm{~kg}$ of milk (cumulative 305-d milk production). The experimental group was administered a feeding regimen during the dry period to induce excess body fat at calving and fatty liver postpartum (Van den Top et al., 1996). The length of the dry period ranged from 62 to $90 \mathrm{~d}$ for the experimental cows and from 55 to $94 \mathrm{~d}$ for the control cows. Each group was presented with the appropriate diet for the entire dry period. To calculate energy balance, the energy requirement for maintenance was taken to be $0.285 \mathrm{MJ}$ of $\mathrm{NE}_{\mathrm{L}} / \mathrm{kg}^{0.75}$ (CVB, 1999). The NEB in the lactating cows (expressed as MJ of $\mathrm{NE}_{\mathrm{L}}$ ) was calculated as [(intake) - (maintenance + milk)] $\times 0.75$. Thus, the calculated NEB value was multiplied by 0.75 . It was assumed that metabolizable energy derived from the body was converted to milk energy by an efficiency of $80 \%$ and that derived from the diet by an efficiency of $60 \%$. In other words, the energy derived from the diet was used $25 \%$ less efficiently $(60 / 80 \times 100 \%)$ than energy derived from the body (NRC, 2001).

All cows were offered the same TMR both pre- and postpartum (Table 1). The feed was offered in two equal portions at 1000 and $2200 \mathrm{~h}$. During the dry period, the control cows were restricted to $6.8 \mathrm{~kg} / \mathrm{d}$ (DM; $47 \mathrm{MJ}$ of $\mathrm{NE}_{\mathrm{L}}$ ) of the TMR, whereas the experimental cows had free access to the same diet. The control cows were fed according to the guidelines based on requirement for dairy cows in the dry period in The Netherlands (CVB, 1999). From $10 \mathrm{~d}$ before calving and during lactation, the diet was also offered to the animals in the control group for ad libitum consumption. To induce a large NEB, the experimental cows were fasted for $8 \mathrm{~h}$ immediately after parturition and were fed restrictedly to $10.1 \mathrm{~kg}$ (DM; $70 \mathrm{MJ}$ of $\mathrm{NE}_{\mathrm{L}}$ ) of the TMR for the first 
$5 \mathrm{~d}$ of lactation. Thereafter, the feed was offered for ad libitum consumption. The cows were housed in a stanchion barn with wheat straw as bedding material. The cows were fed individually and had free access to tap water. The cows were given BCS on a scale of 1 to 5 to the nearest 0.5 .

\section{Sampling and Assay Procedures}

Blood and liver samples were taken at $1 \mathrm{wk}(-5.5 \pm$ $2.4 \mathrm{~d}$ ) before the expected date of calving and at 1,2 , and $4 \mathrm{wk}$ after calving. The blood samples were taken at $1000 \mathrm{~h}$ just before feeding and the liver samples at $1200 \mathrm{~h}$. The samples were collected and handled as in earlier studies (Van den Top et al., 1996).

Concentrations of hepatic TAG (kit number 337-A; Sigma Chemical Co., St. Louis, MO), plasma BHBA (kit number RB 1007; Sanbyo B.V., Uden, The Netherlands), and plasma NEFA (NEFA C, kit number 99475409; Instruchemie B.V., Hilversum, The Netherlands) were measured enzymatically with commercially available kits, as directed by the manufacturers. Measurement of the activities of ACC (EC 6.4.1.2) and FAS (EC 2.3.1.85) were performed as described previously (Tijburg et al., 1988). To avoid interference of the assay by mitochondrial enzymes, ACC activity was measured by monitoring the incorporation of radiolabeled acetylCoA into fatty acids, i.e., by coupling the carboxylase reaction to the FAS reaction (Bijleveld and Geelen, 1987). The activities of 3-HAD (EC 1.1.1.35) and CS (EC 2.3.3.1) were determined spectrophotometrically as described by Passonneau and Lowry (1993) and Stitt (1983). Preliminary experiments defined optimal conditions of enzyme assays for bovine liver tissue in terms of time and protein concentration.

\section{Statistical Analysis}

Data from the control and the experimental groups were expressed as means \pm SEM. To disclose time and diet effects, blood and liver data were subjected to repeated measures, one-way ANOVA. The prepartum data were evaluated with Student's $t$ test. The level of statistical significance was preset at $P<0.05$.

\section{RESULTS}

\section{Performance}

In the dry period, control cows consumed $6.8 \mathrm{~kg}$ of $\mathrm{DM} / \mathrm{d}$. The feed consumption of the experimental cows with free access to feed was $13.2 \pm 1.1 \mathrm{~kg}$ of $\mathrm{DM} / \mathrm{d}$ in the period from 20 to $10 \mathrm{~d}$ before parturition. In the 10 $\mathrm{d}$ before calving, i.e., the period that both groups had free access to feed, experimental cows consumed 10.4 $\pm 1.1 \mathrm{~kg}$ of DM/d and control cows $12.7 \pm 1.5 \mathrm{~kg}$ of DM/ $\mathrm{d}$. The DMI during the first week after parturition was $9.0 \pm 0.9 \mathrm{~kg} / \mathrm{d}$ for the experimental group and $16.1 \pm$ $1.9 \mathrm{~kg} / \mathrm{d}$ for the control group. It should be noted that the animals in the experimental group were fed restrictedly for the first $5 \mathrm{~d}$ postpartum. For the period of 2 wk after parturition, DMI had increased to $12.8 \pm 1.3$ $\mathrm{kg} / \mathrm{d}$ for experimental cows and to $17.2 \pm 1.3 \mathrm{~kg} / \mathrm{d}$ for control cows.

During the dry period, experimental cows consumed more energy than did control cows, and, as a result, mean BW gain was greater $(P<0.028)$ for experimental cows than for control cows, as designed $[103.0 \pm 7.9 \mathrm{~kg}$ vs. $75.5 \pm 9.4 \mathrm{~kg}$ ]. At the end of the dry period, the BCS for the experimental group were higher $(P<0.001)$ than for the control group $(4.7 \pm 0.1$ vs $3.0 \pm 0.2)$. After parturition, mean BW loss (i.e., the difference between BW measured immediately after parturition and that $4 \mathrm{wk}$ later) was greater $(P<0.009)$ for experimental cows than for control cows [55.7 $\pm 13.2 \mathrm{~kg}$ vs. $28.0 \pm 17.1 \mathrm{~kg}]$. At 4 wk postpartum, the BCS dropped $33 \%$ in experimental cows and $23 \%$ in control cows $(3.2 \pm 0.2$ vs. 2.3 \pm 0.2 ). During the first through the fourth weeks of lactation, mean milk production was $27.3 \pm 1.8 \mathrm{~kg} / \mathrm{d}$ for experimental cows and $29.6 \pm 1.5 \mathrm{~kg} / \mathrm{d}$ for control cows and did not differ between the two groups.

Energy balance at $1 \mathrm{wk}$ after parturition in the experimental group $\left(-38.3 \pm 4.8 \mathrm{MJ}\right.$ of $\left.\mathrm{NE}_{\mathrm{L}} / \mathrm{d}\right)$ was more negative $(P<0.009)$ than in the control group $(-1.4 \pm 12.0 \mathrm{MJ}$ of $\left.\mathrm{NE}_{\mathrm{L}} / \mathrm{d}\right)$. In the second week postpartum, the energy balance was still more negative $(P<0.022)$ in experimental cows $\left(-25.6 \pm 3.8 \mathrm{MJ} \mathrm{NE}_{\mathrm{L}} / \mathrm{d}\right)$ than in control cows $\left(-9.0 \pm 5.6 \mathrm{MJ} \mathrm{NE}_{\mathrm{L}} / \mathrm{d}\right)$. The cows in the experimental group maintained the NEB state longer than did the control group.

\section{NEFA and BHBA}

The combination of factors imposed on the experimental cows resulted in groups with widely differing NEFA and BHBA plasma concentrations. The concentrations of NEFA did not differ between the two groups at 1 wk before parturition but rose sharply after parturition in both groups (Figure 1). Compared to the concentration at $1 \mathrm{wk}$ before parturition, the concentration at $1 \mathrm{wk}$ after parturition had increased 3 -fold $(P<0.001)$ in the experimental group but increased only by $67 \%$ in the control group. For the postpartum NEFA concentrations there was a significant treatment effect $(P=$ $0.050)$ and time effect $(P=0.038)$, but no interaction of time and treatment $(P=0.179)$. Mean plasma BHBA concentrations were not different between the two groups before parturition. In the control group the concentration rose slightly following parturition, but this 

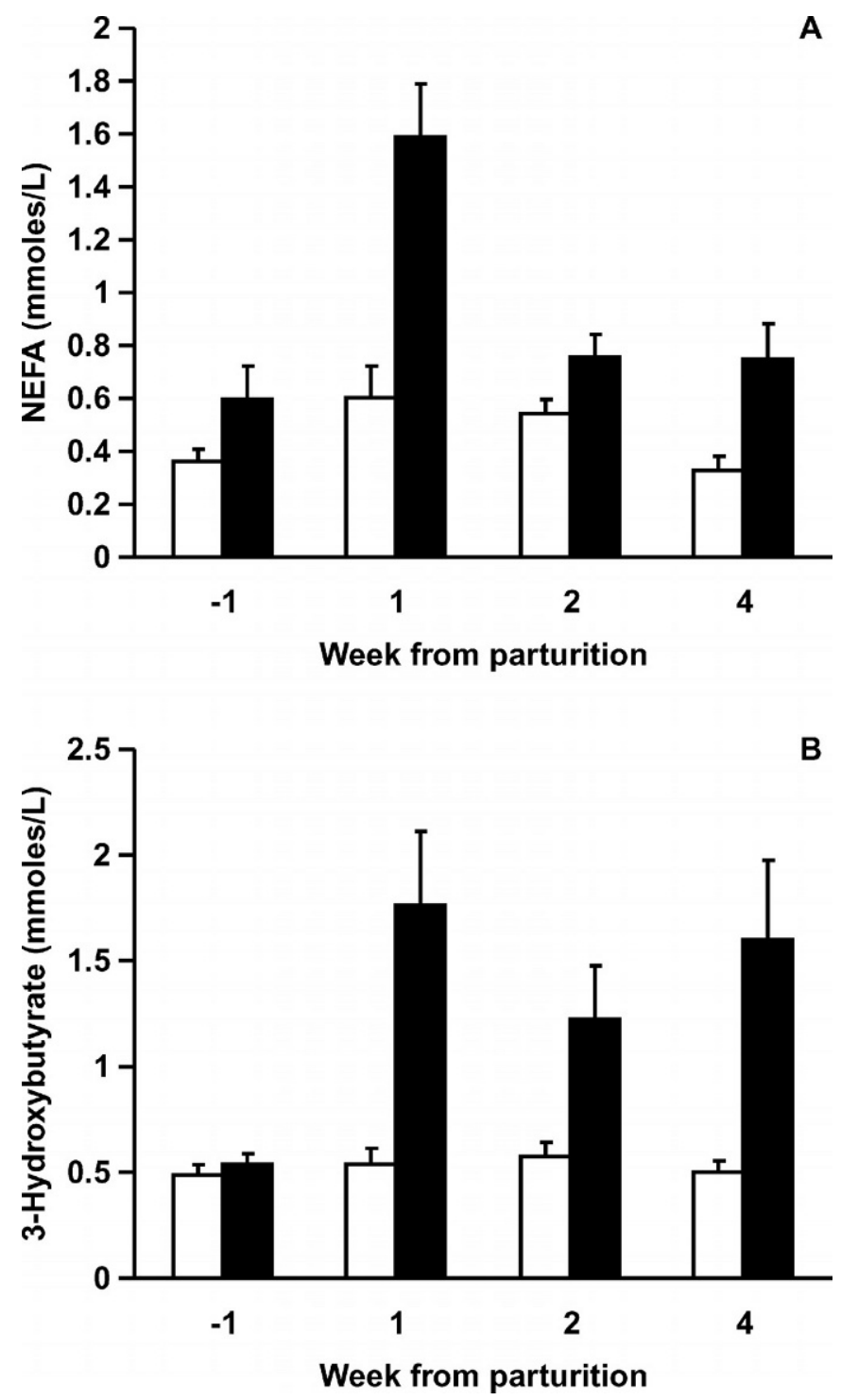

Figure 1. Ante and postpartum plasma concentrations (mean \pm SEM) of (A) NEFA; $P$ values for treatment 0.050 , for time 0.038 , and for time $\times$ treatment interaction 0.179 , (B) 3-hydroxybutyrate, measured in control cows $(n=7 ; \square)$ and experimental cows $(n=10$; 口); $P$ values for treatment 0.016 , for time 0.151 , and for time $\times$ treatment interaction 0.034 .

rise was not significant. However, the concentration rose in the experimental group following parturition $(P=0.016)$. There was no time effect $(P=0.151)$, but there was an interaction of time and treatment $(P=$ $0.034)$.

\section{Hepatic TAG}

At 1 wk before parturition, the liver TAG levels were similar in the two groups of cows (Figure 2). Consistent with previous observations (Grummer et al., 1990; Har-

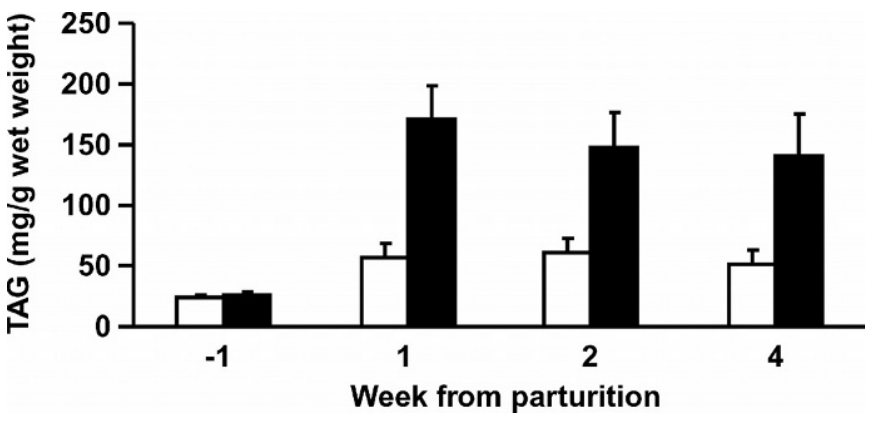

Figure 2. Ante and postpartum hepatic concentrations (mean \pm SEM) of triacylglycerols (TAG), measured in control cows $(\mathrm{n}=7 ; \square)$ and experimental cows $(\mathrm{n}=10 ; \mathbf{\square}) ; P$ values for treatment 0.018 , for time 0.081 , and for time $\times$ treatment interaction 0.482 .

rison et al., 1990; McNamara, 1991; Van den Top et al., 1996), the mean concentrations in the two groups rose sharply at $1 \mathrm{wk}$ after parturition and remained higher throughout the postpartum sampling period. The rise was markedly greater in the experimental cows than in the control cows. There was a significant treatment effect $(P=0.018)$, but no time effect $(P=0.081)$ and no interaction of time and treatment $(P=0.482)$.

\section{Enzyme Activities of Hepatic Fatty Acid Synthesis}

In homogenates of liver biopsies, the activities of ACC and FAS were determined to assess the hepatic capacity for fatty acid synthesis (Figure 3). In experimental cows compared with control cows the activity of ACC was less $(P<0.018)$ at $1 \mathrm{wk}$ before parturition. After parturition, ACC activities dropped quite sharply in the experimental group and remained lower throughout the sampling period than the values seen in the control group $(P<$ $0.011)$. There was no effect of time $(P=0.684)$ and no time $\times$ treatment interaction $(P=0.331)$. As a cofactor, prepartum ACC activity had no significant effect in the one-way ANOVA of the postpartum values. Prepartum FAS activities were not different. There was a postpartum treatment effect $(P=0.004)$, but no time effect $(P=0.173)$ or time $\times$ treatment interaction $(P=0.267)$ occurred for this enzyme activity.

\section{Enzyme Activities of Hepatic Fatty Acid Oxidation}

The activities of 3-HAD and CS were determined in liver homogenates as indicators of the hepatic capacity for fatty acid oxidation and Krebs cycle activity (Figure 4). There were no changes in the activities of 3-HAD in the control cows, i.e., they were similar before and after parturition. In experimental cows, this enzyme activity was slightly less than in control cows at $1 \mathrm{wk}$ before parturition and dropped significantly $(P=0.002)$ 

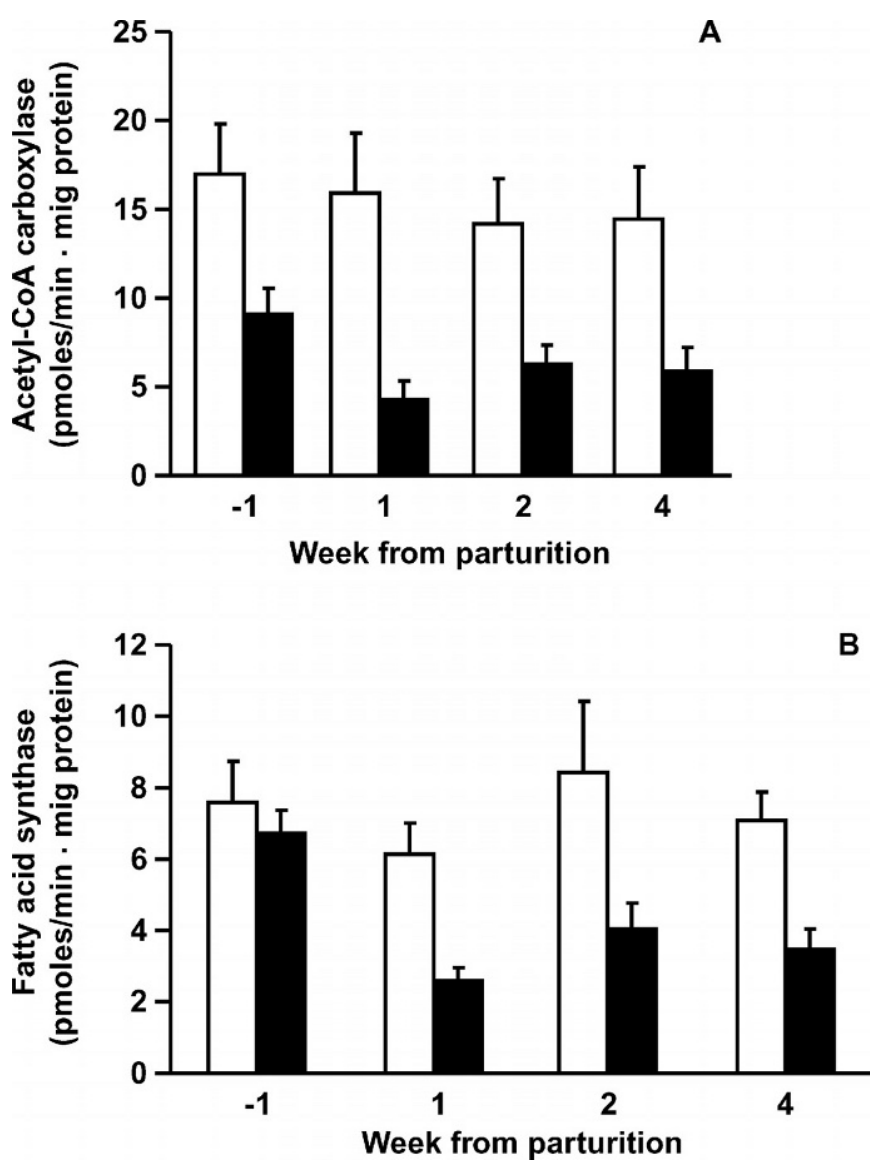

Figure 3. Ante and postpartum hepatic activities (mean \pm SEM) of (A) acetyl-CoA carboxylase (ACC); $P$ values for treatment 0.011 , for time 0.684 , and for time $\times$ treatment interaction 0.311 , (B) fatty acid synthase (FAS) in control cows $(\mathrm{n}=7 ; \square)$ and experimental cows $(\mathrm{n}=10 ; \square)$; $P$ values for treatment 0.004 , for time 0.173 , and for time $\times$ treatment interaction 0.267 .

following parturition. This enzyme activity did not show a time effect $(P=0.623)$ or time $\times$ treatment interaction $(P=0.356)$. Before parturition, the activities of CS for the two groups were not different. In the experimental group CS activity remained unaffected throughout sampling. In the control group, the activities of this enzyme had increased postpartum $(P=0.001)$ compared with the prepartum time and stayed elevated throughout sampling. Again, there was no time effect $(P=0.365)$ or time $\times$ treatment interaction $(P<0.132)$.

\section{DISCUSSION}

Consistent with our previous observations (Van den Top et al., 1996; Rukkwamsuk et al., 1998), cows with unrestricted access to feed in the dry period lost more BW during the first 4 wk after parturition than did cows that were limit-fed in the dry period. This indicates that experimental cows had a more severe NEB postpartum
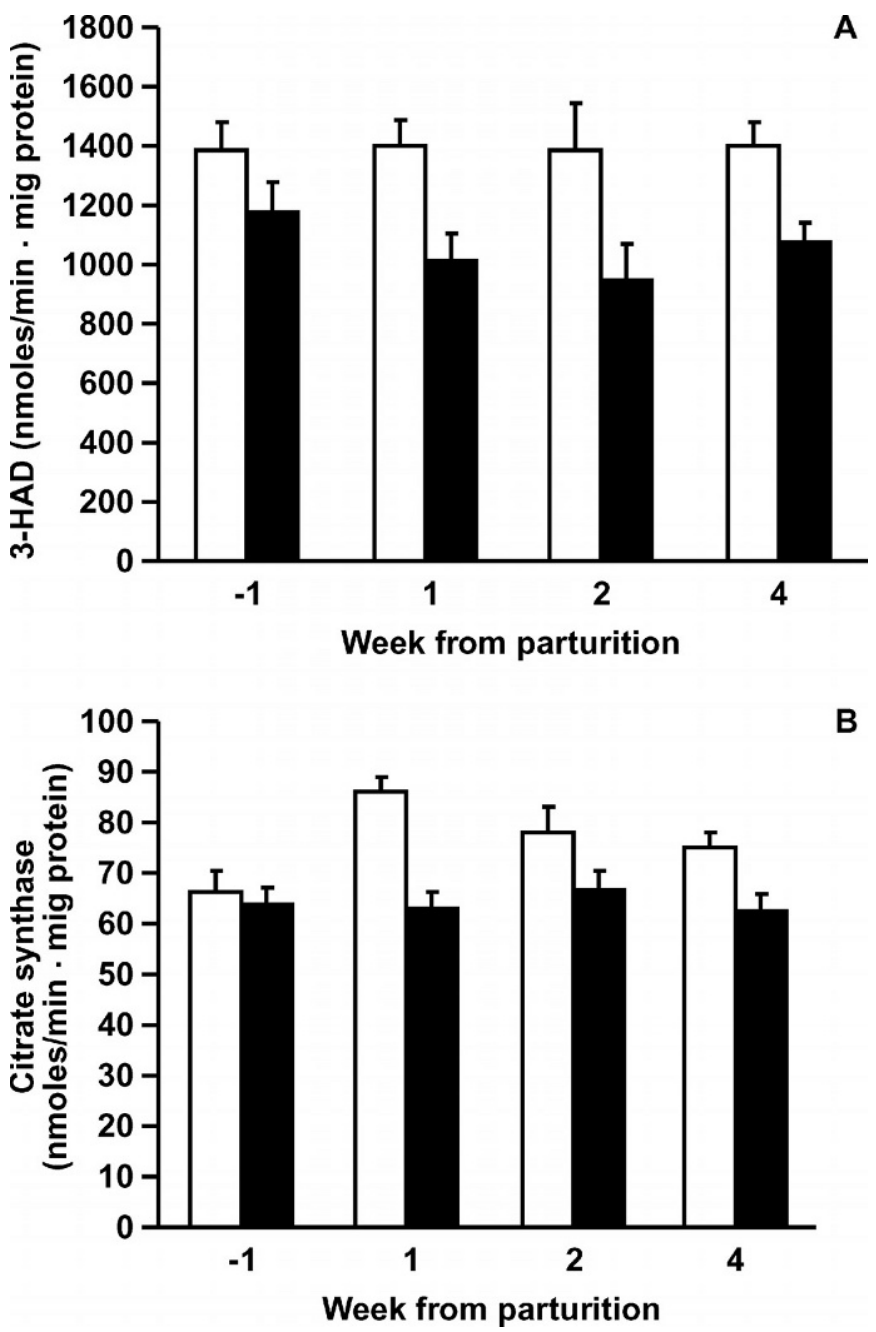

Figure 4. Ante and postpartum hepatic activities (mean $\pm \mathrm{SEM}$ ) of (A) 3-hydroxyacyl-CoA dehydrogenase (3-HAD); $P$ values for treatment 0.002 , for time 0.623 , and for time $\times$ treatment interaction 0.356 , (B) citrate synthase $(\mathrm{CS})$ in control cows $(\mathrm{n}=7 ; \square)$ and experimental cows $(\mathrm{n}=10$; $) P$ values treatment 0.001 , for time 0.365 , and for time $\times$ treatment interaction 0.132 .

than control cows, which was indeed the case, and thus had greater mobilization of body fat after parturition. This reasoning is supported by a significantly higher serum NEFA concentration in the experimental cows. An increased concentration of serum NEFA is associated with an increase in TAG synthesis in the liver (Herdt, 1988; Van den Top et al., 1996; Mashek et al., 2001). This was also confirmed by the present study, which showed that experimental cows accumulated greater amounts of TAG in the liver after parturition. Hepatic concentrations in the present study were of the same order of magnitude as those observed in our earlier studies (Van den Top et al., 1996; Rukkwamsuk et al., 1998). 
The fatty acids accumulated in hepatic TAG can also be derived from de novo synthesized fatty acids in the liver. The adipose tissue and not the liver is thought to be the major site of fatty acid synthesis in the nonlactating ruminant, based on some studies done using radiolabeled acetate with in vitro tissue slice incubations (Bell, 1979; Vernon, 1980). However, the capacity for hepatic fatty acid synthesis in dairy cows at the onset of lactation is not known. Increasing hepatic fatty acid synthesis at that time could contribute to postpartum development of fatty liver. On the other hand, as there is little logic to expect that hepatic fatty acid synthesis would be important to dairy cows in NEB, the activity of ACC might well be instrumental in regulating the rate of long-chain fatty acid uptake into liver mitochondria via the concentration of malonyl-CoA, inhibitor of carnitine palmitoyltransferase-I. Low activities of ACC and FAS were observed in liver biopsies of cows in this experiment. The activity of ACC was significantly lower before parturition in the experimental group. The activity of ACC is regulated by the concentrations of fatty acids and hormones (Geelen et al., 1980; Kim, 1997; Sul and Wang, 1998). The concentration of fatty acids may not have been responsible for the low activity of ACC before parturition as there was no significant difference in the plasma NEFA concentration between the two groups before parturition (Figure 1). However, tissue concentrations of fatty acids may have been different from plasma concentrations. A low concentration of insulin before parturition in the experimental group compared with the control group could explain a drop in ACC activity at that time. This explanation is not very likely either as in a previous experiment the serum insulin concentration before parturition tended to be higher in cows developing fatty liver than in control cows (Rukkwamsuk et al., 1998). Higher insulin levels are consistent with the notion that cows affected with fatty liver suffer from insulin resistance (Ohtsuka et al., 2001). One of the hormones that potentially can affect the rate of hepatic lipogenesis is leptin. In mice, leptin inhibited hepatic lipogenesis (Bryson et al., 1999). In ruminants, maternal leptin is elevated during pregnancy (Ehrhardt et al., 2000) and decreases by 50\% after parturition (Block et al., 2001). A higher prepartum concentration of leptin in experimental cows than in control cows could explain the lower capacity for fatty acid synthesis in the former group. The sustained low activities of the lipogenic enzymes postpartum in the present experiment is, however, inconsistent with a drop in leptin following parturition. Estrogen may be an important factor contributing to the postpartum development of fatty liver as serum estrogen levels increase about a 100 -fold immediately prepartum, and treatment of cows in late lactation with estradiol in- creased hepatic lipid accumulation (Grummer et al., 1990). Other hormones may be involved as data collected by a number of laboratories indicate that the dramatic endocrine changes in the periparturient cow contribute to NEFA mobilization and, thus, to the development of fatty liver (Grummer et al., 1990; Bauman and Vernon, 1993). High levels of circulating fatty acids postpartum, as seen in the present study in the experimental group, may also reduce the activity of ACC and FAS (Wakil et al., 1983). Indeed, dietary fatty acids have been shown to suppress the gene expression of FAS (Clarke et al., 1990).

High ACC activity relative to FAS activity observed in the present study might be a reflection of the fact that ACC in bovine liver is involved in controlling fatty acid oxidation rather than providing intermediates for fatty acid synthesis. Experimental studies have identified two isoforms of $\mathrm{ACC}$, i.e., a $280-\mathrm{kDa}$ isoform $\left(\mathrm{ACC}_{280}\right)$ and a $265-\mathrm{kDa}$ isoform $\left(\mathrm{ACC}_{265}\right)$ (Thampy, 1989). From the results of several studies it was concluded that $\mathrm{ACC}_{265}$ is part of the lipogenic sequence and that $\mathrm{ACC}_{280}$ functions in the regulation of fatty acid oxidation (Saddik et al., 1993; Lopaschuk et al., 1994). In sheep liver, Moibi et al. (2000) detected only the $\mathrm{ACC}_{265}$ isoform. It would be interesting to know whether bovine liver has an $\mathrm{ACC}_{280}$ isoform and what the $\mathrm{ACC}_{265} / \mathrm{ACC}_{280}$ ratio is in bovine liver.

It is not possible to deduce flux changes through metabolic paths from enzyme activities, measured under $\mathrm{V}_{\max }$ conditions. Nevertheless it is worth projecting the observed changes of hepatic CS (Krebs cycle) and 3HAD ( $\beta$-oxidation) against the metabolic profiles of experimental and control cows. In the control cows, the higher postpartum activity of hepatic CS correlates with an increased energy requirement at the onset of lactation. This is in contrast to the livers of the experimental cows, in which CS was not enhanced postpartum. A surprising finding was the lower activity of 3HAD postpartum in the livers of the experimental cows, especially in the face of elevated levels of BHBA. Despite the increase in plasma NEFA concentration and the plasma BHBA level, the activity of 3-HAD was decreased. This suggests that under these circumstances 3 -HAD is not limiting the rate of $\beta$-oxidation, which provides sufficient energy to suppress the Krebs cycle. Hence, there is overflow of acetyl-CoA and enhanced production of BHBA. Modulation of the HMG-CoA synthase activity within the ketogenic pathway by succinylation/desuccinylation (Hegardt, 1999) might well contribute to the strong ketogenic response. Although there can be no doubt based on all the observations that the increase in fat in liver is due to a dramatic increase in NEFA supply, recent publications (Drackley, 1999; Drackley et al., 2001) suggest that depressed or limited 
fatty acid oxidation would contribute to the increased TAG. Our data are consistent with that notion.

Malonyl-CoA, the product of the reaction catalyzed by ACC, is not only an intermediate in de novo fatty acid synthesis but also a physiological inhibitor of carnitine palmitoyltransferase-I, one of the key regulatory enzymes of fatty acid oxidation. A decrease in the activity of ACC-as observed in the experimental group-will lower the malonyl-CoA concentration and thus increase the translocation of fatty acids into mitochondria, which will result in enhanced $\beta$-oxidation. As the capacity of the Krebs cycle is not changed in experimental cows, judged from unaltered CS activity, enhanced ketogenesis will ensue. That is indeed what was observed in this experiment. The decrease in activity of 3-HAD, possibly by increased mitochondrial $\mathrm{NADH} / \mathrm{NAD}^{+}$concentration ratio, might be an attempt to dampen the spectacular rate of ketogenesis occurring in experimental cows.

In conclusion, the results of this study show that cows with unrestricted access to feed during the dry period have postpartum 1) a reduction in Krebs cycle capacity and 2) low activities of the key enzymes of de novo fatty acid synthesis and fatty acid oxidation in liver. Thus, the observed hepatic TAG accumulation in these cows may be increased in part by a depressed fatty acid oxidation in the liver, whereas the inhibition of de novo fatty acid synthesis only dampens further TAG accumulation.

\section{ACKNOWLEDGMENTS}

The authors acknowledge the expert technical assistance of Ine Geelen-van Eeden. Research was supported in part by the Netherlands Foundation for Chemical Research (SON) with financial aid from The Netherlands Organization for Scientific Research (NWO).

\section{REFERENCES}

Bauman, D. E., and R. G. Vernon. 1993. Effects of exogenous bovine somatotropin on lactation. Annu. Rev. Nutr. 13:437-461.

Bell, A. W. 1979. Lipid metabolism in liver and selected tissues and in the whole body of ruminant animals. Prog. Lipid Res. 18:117-164.

Block, S. S., W. R. Butler, R. A. Ehrhardt, A. W. Bell, M. E. Van Amburgh, and Y. R. Boisclair. 2001. Decreased concentration of leptin in periparturient dairy cows is caused by negative energy balance. J. Endocrinol. 171:339-348.

Bryson, J. M., J. L. Phuyal, V. Swan, and I. D. Caterson. 1999. Leptin has acute effects on glucose and lipid metabolism in both lean and gold thioglucose-obese mice. Am. J. Physiol. 277:17-22.

Bijleveld, C., and M. J. H. Geelen. 1987. Measurement of acetylCoA carboxylase in isolated hepatocytes. Biochim. Biophys. Acta 918:274-283.

Clarke, S. D., M. K. Armstrongand, and D. B Jump. 1990. Dietary polyunsaturated fats uniquely suppress rat liver fatty acid synthase and S14 mRNA content. J. Nutr. 120:225-231.

CVB. 1999. Centraal Veevoederbureau, Tabellenboek Veevoeding, Lelystad, The Netherlands.

Drackley, J. K. 1999. Biology of dairy cows during the transition period: The final frontier? J. Dairy Sci. 82:2259-2273.
Drackley, J. K., T. R. Overton, and G. N. Douglas. 2001. Adaptations of glucose and long-chain fatty acid metabolism in liver of dairy cows during the periparturient period. J. Dairy Sci. 84(E. Suppl.):E100-E112.

Ehrhardt, R. A., R. M. Slepetis, A. W. Bell, and Y. R. Boisclair. 2000. Maternal leptin is elevated during pregnancy in sheep. Domest. Anim. Endocrinol. 21:85-96.

Geelen, M. J. H., R. A. Harris, A. C. Beynen, and S. A. McCune. 1980. Short-term hormonal control of hepatic lipogenesis. Diabetes 29:1006-1022.

Gerloff, B. J., H. T. Herdt, and R. S. Emery. 1986. Relationship of hepatic lipidosis to health and performance in dairy cattle. J. Am. Vet. Med. Assoc. 188:845-850.

Grummer, R. R., S. J. Bertics, D. W. Lacount, J. A. Snow, M. R. Dentine, and R. H. Stauffacher. 1990. Estrogen induction of fatty liver in dairy cows. J. Dairy Sci. 73:1537-1543.

Grummer, R. R. 1995. Impact of changes in organic nutrient metabolism on developing feeding strategies to minimise stress during transition from late pregnancy to early lactation. J. Anim. Sci. 73:2820-2833.

Guzmán, M., and M. J. H. Geelen. 1993. Regulation of fatty acid oxidation in mammalian liver. Biochim. Biophys. Acta 1167:227-241.

Harrison, R. O., S. P. Ford, J. W. Young, A. J. Conley, and A. E. Freeman. 1990. Increased milk production versus reproductive and energy status of high producing dairy cows. J. Dairy Sci. 73:2749-2758.

Hegardt, F. G. 1999. Mitochondrial 3-hydroxy-3-methylglutaryl-CoA synthase: A control enzyme in ketogenesis. Biochem. J. 338:569-582.

Herdt, T. H. 1988. Metabolic diseases of ruminant livestock: Fuel homeostasis in the ruminant. Vet. Clin. North Am. Food Anim. Pract. 4:213-231.

Kim, K.-H. 1997. Regulation of mammalian acetyl-coenzyme A carboxylase. Annu. Rev. Nutr. 17:77-99.

Lopaschuk, G. D., D. D. Belke, J. Gamble, T. Itoi, and B. O. Schnekess. 1994. Regulation of fatty acid oxidation in the mammalian heart in health and disease. Biochim. Biophys. Acta 1213:263-276.

Mashek, D. G., S. J. Bertics, and R. R. Grummer. 2001. Metabolic fate of long-chain unsaturated fatty acids and their effects on palmitic acid metabolism and gluconeogenesis in bovine hepatocytes. J. Dairy Sci. 85:2283-2289.

McNamara, J. P. 1991. Regulation of adipose tissue metabolism in support of lactation. J. Dairy Sci. 74:706-719.

Moibi, J. A., R. J. Christopherson, and E. K. Okine. 2000. Effect of environmental temperature and dietary lipid supplement on activity and protein abundance of acetyl-CoA carboxylase and fatty acid synthase in skeletal muscle, liver and adipose tissue of sheep. Can J. Anim. Sci. 80:69-77.

NRC. 2001. Nutrient Requirements of Dairy Cattle. 7th rev. ed. Natl. Academy Press, Washington, DC.

Ohtsuka, H., M. Koiwa, A. Hatsugaya, K. Kudo, F. Hoshi, N. Itoh, H. Jokota, H. Okada, and S. Kawamura. 2001. Relationship between serum TNF activity and insulin resistance in dairy cows affected with naturally occurring fatty liver. J. Vet. Med. Sci. 63:10211025 .

Oikawa, S., N. Katoh, F. Kawawa, and Y. Ono. 1997. Decreased serum apolipoprotein B100 and A1 concentrations in cows with ketosis and left displaced abomasum. Am. J. Vet. Res. 58:121-125.

Passonneau, J. V., and O. H. Lowry. 1993. Pages 274-275 in Enzymatic Analysis. Humana Press Inc. Totowa, NJ.

Rukkwamsuk, T., T. Wensing, and M. J. H. Geelen. 1998. Effect of overfeeding during the dry period on regulation of adipose tissue metabolism in dairy cows during the periparturient period. J. Dairy Sc. 81:2904-2911.

Saddik, M., J. Gamble, L. A. Witters, and G. D. Lopaschuk. 1993. Acetyl-CoA carboxylase regulation of fatty acid oxidation in the heart. J. Biol. Chem. 268:25836-25845.

Stitt, M. 1983. Citrate synthase. Pages 353-358 in Methods in Enzymatic Analysis. H. U. Bergmeyer, ed. Verlag Chemie, Weinheim, Germany. 
Sul, H. S., and D. Wang. 1998. Nutritional and hormonal regulation of enzymes of fat synthesis: Studies of fatty acid synthase and mitochondrial glycerol-3-phosphate acyltransferase gene transcription. Annu. Rev. Nutr. 18:331-351.

Thampy, K. G. 1989. Formation of malonyl coenzyme A in rat heart. Identification and purification of an isozyme of acetyl coenzyme A carboxylase from rat heart. J. Biol. Chem. 264:17631-17634.

Tijburg, L. B. M., A. Maquedano, C. Bijleveld, M. Guzmán, and M. J. H. Geelen.1988. Effects of ethanol feeding on hepatic lipid synthesis. Arch. Biochem. Biophys. 267:568-579.

Treacher, R. J., I. M. Read, and C. J. Roberts. 1986. Effect of body condition at calving on the health and performance of dairy cows. Anim. Prod. 43:1-6.

Van den Top, A. M., M. J. H. Geelen, T. Wensing, G. H. Wentink, A. T. van 't Klooster, and A. C. Beynen. 1996. Higher postpartum hepatic triacylglycerol concentrations in dairy cows with free versus restricted access to feed during the dry period are associated with lower activities of hepatic glycerolphosphate acyltransferase. J. Nutr. 126:76-85.

Vernon, R. G. 1980. Lipid metabolism in the adipose tissue of ruminant animals. Prog. Lipid Res. 19:23-106.

Wakil, S. J., J. K. Stoops, and V. C. Joshi. 1983. Fatty acid synthesis and its regulation. Annu. Rev. Biochem. 52:537-579.

Waltner, S., J. P. McNamara, and J. K. Hillers. 1993. Relationship of body condition score to production variables in high producing, Holstein dairy cattle. J. Dairy Sci. 76:3410-3419.

Zurek, E., G. R. Foxcroft, and J. J. Kennelly. 1995. Metabolic status and interval to first ovulation in postpartum dairy cows. J. Dairy Sci. 78:1909-1920. 